\title{
Freezing-resistant liquid water in porous media, a possible mechanism to account for the fluidized transport of sediments on Mars: an example from East Gorgonum crater
}

\author{
Roberto Oyarzun, ${ }^{1}$ Cristóbal Viedma, ${ }^{1}$ Alvaro Márquez ${ }^{2}$ and Javier Lillo ${ }^{2}$ \\ ${ }^{1}$ Departamento de Cristalografía y Mineralogía, Facultad de C.C. Geológicas, Universidad Complutense, 28040 Madrid, Spain; ${ }^{2}$ Escuela \\ Superior de Ciencias Experimentales y Tecnología, Universidad Rey Juan Carlos, Tulipán s/n, 28933 Móstoles (Madrid), Spain
}

\begin{abstract}
A mudflow-like deposit resting on the bottom of the East Gorgonum Crater (Mars; $37.4^{\circ} \mathrm{S}, 168.0^{\circ} \mathrm{W}$ ) may provide new insight regarding the debate on the existence of water over the Martian surface. Because water in a mudflow is confined to a porous medium, we analyse this case from the perspective of non-equilibrium systems. Fluids confined to porous media behave in a special way, the system being ruled by kinetic restrictions, which alter the expected thermodynamic equilibrium. These non-equilibrium conditions allow the existence of pure liquid water to temperatures as low as $-40^{\circ} \mathrm{C}$, and even less if the system includes brines. Thus, application of the triple
\end{abstract}

point diagram of water on the Martian surface may constitute a simplistic approach if we are dealing with confined, and yet moving, water in the form of a mudflow. We further suggest that the V-shaped channels excavated alongside the mudflow may have been caused by water rejected by syneresis from the moving sediment. We finally indicate that the series of deeply entrenched channels and debris aprons that occur only in the northern half of the crater might be related to the regional slope, which decreases in altitude to the south.

\section{Introduction}

The debate on the existence of water on Mars has lasted for many years. Contrary to what might have been foreseen, the arrival of high-resolution images from the Mars Global Surveyor has merely stirred the debate further (e.g. Hoffman, 2000; Malin and Edget, 2000, among others). Several papers strongly suggest the existence of water beneath the Martian surface (e.g. Malin and Edget, 2000; Baker, 2001; Costard et al., 2001, 2002; Hartmann, 2001; Jakosky and Phillips, 2001; Mellon and Phillips, 2001; Gilmore and Phillips, 2002; Knauth and Burt, 2002; Christensen, 2003, among others). This idea is supported by geomorphic features on Martian impact craters, south polar pits and valleys indicating groundwater seepage and surface runoff. In contrast, Hoffman (2000) proposes that many of these geomorphic features may have been originated by flows generated by the extensional collapse of unstable rock masses at

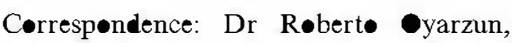
Departament• de Cristaløgrafia y Mineraløgía, Facultad de C.C. Geølógicas, Universidad Complutense, 28040 Madrid, Spain. E-mail: •yarzun@ge•.ucm.es the foot of cliffs, closely resembling volcanic avalanches. In fact the analogy goes further, because Hoffman (2000) suggests that these flows would be akin to terrestrial gas-supported pyroclastic flows such as ignimbrites or surges, only at very low temperatures, with $\mathrm{CO}_{2}$ as the main gaseous phase.

We here discuss an elongated sedimentary deposit in East Gorgonum Crater on Mars $\left(37.4^{\circ} \mathrm{S}, 168.0^{\circ} \mathrm{W}\right)$ (Fig. 1) resembling in many aspects a terrestrial mudflow-type deposit (Fig. 2), which strongly suggests that liquid water may be, or may have been, present in Gorgonum. We suggest a possible mechanism to account for the integrity of liquid water within a moving fluidized sediment despite restrictive external $\boldsymbol{P}-T$ conditions.

\section{Mudflow deposits in East Gorgonum crater: thermodynamic considerations}

Mudflows are common in arid and semi-arid regions that receive short but intense rainstorms (Fig. 2). Snow melting may provide an additional source of saturation water. These factors convert the regolith into a mass of viscous mud that can move downslope at high velocity. Mudflows (or muddy debris flows) are considered a type of gravity mass flows characterized by non-Newtonian viscoplastic rheology, for which the whole sediment concentration by volume is $50-90 \%$ (note that not much water is involved in large mobilized volumes) with a fine fraction above $10 \%$ (e.g. Coussot and Meunier, 1996). Thus, mudflows are flows of transient nature, comprising a mixture of liquid water - solid matter in which both components move in unison, in most cases under a laminar regime. The high volumetric sediment concentration distinguishes mudflows and debris flows from natural Newtonian flows (such as 'normal' density currents and water two-phase floods) which normally have a volumetric sediment content below 25\%. Mudflows and debris flows must be considered as materials that undergo changes of state. They originate from nearly rigid state, move fluidly and eventually form deposits in a nearly rigid state. Mudflows may have a Newtonian hyperconcentrated flow tail when the solid concentration becomes smaller than a critical value, which may be caused by water/sediment availability during the flow. Thus, most shear resistance in debris flows is generated by Coulomb friction $\left[\tau=\sigma\left(\tan \varphi_{s}\right)\right.$, where $\tau$ represents bulk intergranular 

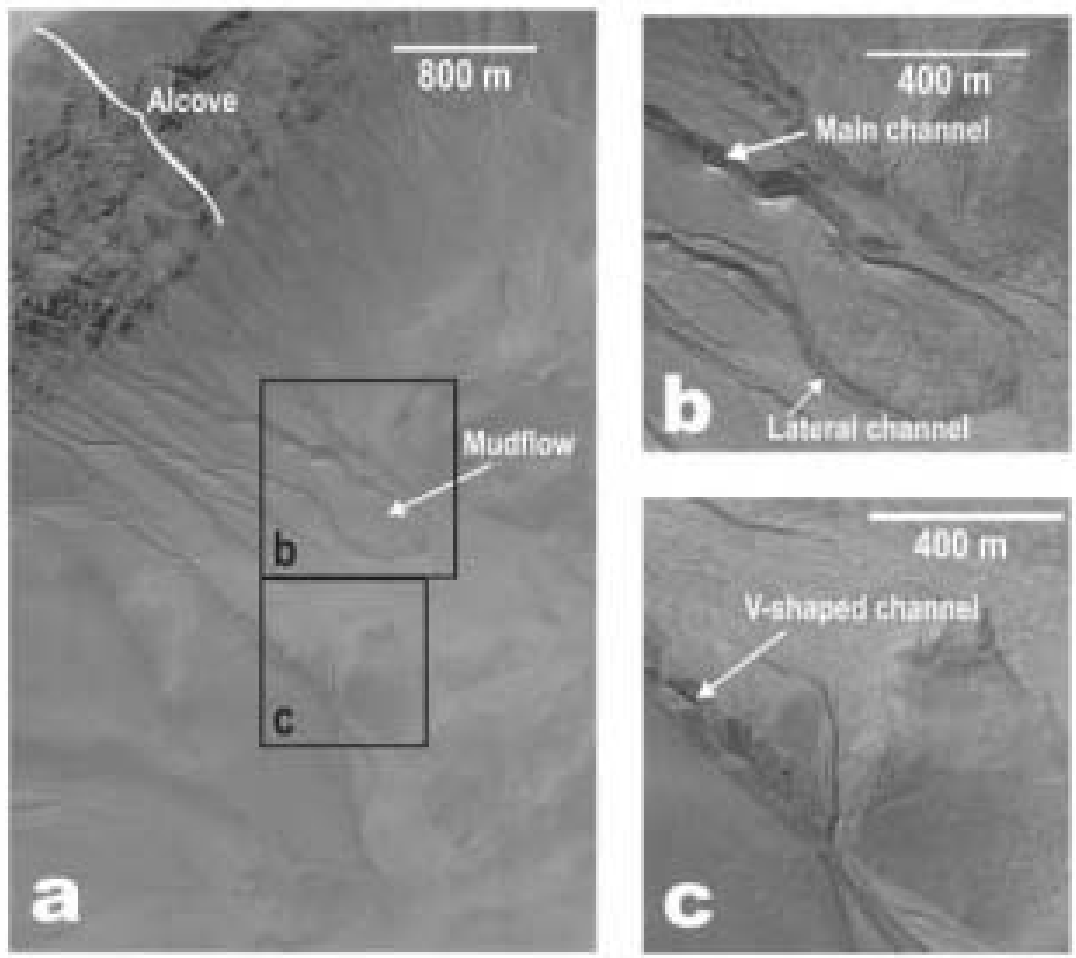

Fig. 1 Northesn sector of the East Gergonum arater. Note the head alcove (a), representing a source mosphology (Malin and Edget, 2wo); detail of a mudflow-like deposit (b); and a V-shaped channel (c). MOC images M\$1873, M14183 M15 1466; see alsø MGS MOC Release N•. Moce-241.

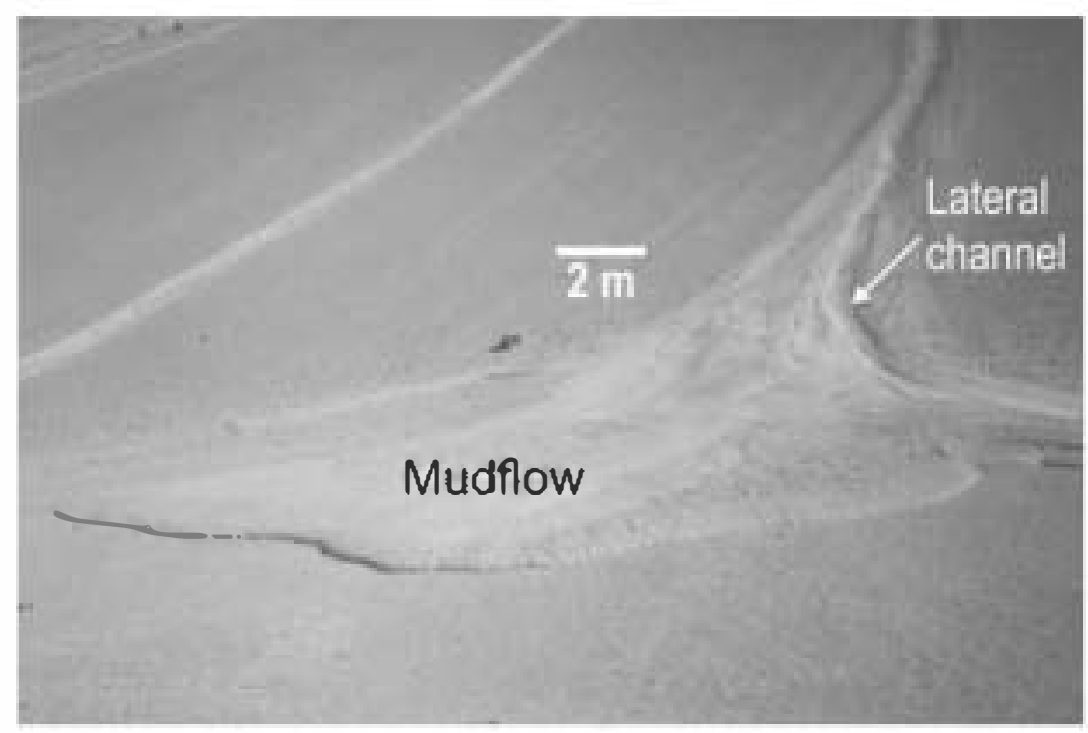

Fig. 2 Recent mudflow in the Atacama desert (northern Quile). Road from Coriapo to Maricunga (23\% $\mathrm{m}$ above sea level). Note the asseciated lateral cliannel on the right.

shear stress, $\sigma$ inteigranular neimal stress and $\varphi_{s}$ the static frictional angle]. deeply entrenched channels, debris aprens (Malin Space Systerns, 201) and a well-decumented $\sim 2-\mathrm{km}$-leng, 350-m-wide (maximum), frent-leked geemerphic feature that clesely resembls a terrestrial mudflew depesit (Fig. la,b). We are aware of the many theim odynamic censiderations ruling eut the existence of liquid water en the surface of Mars (e.g. Hofiman, 2000, ameng ethers). Fer example, the extramely low pressures in the region of Gergenum (4.5 5.5 mbar; Nasa Ames Mars General Circulatien Mode1, 2002) are belew that of the water tiiple peint ( $\sim 6.1 \mathrm{mbar}$ ). Thus, altheugh the highest temperatures in this zene may reach up to $290 \mathrm{~K}$ (Nasa Ames Mars General Circulation Model, 2002), pressure constraints enly allew a phase change from solid to gas. Hewever, in the Gergenum case we weuld net be dealing with a typical case of en-suifacefree-water, but with water cenfried to a perens material (i.e. a mudflew). This makes a censiderable difference because under such conditions the classic thermedynamic appreach (phase diagram fer water) may net apply. Fer example, as early as the 1960 s it was recegnized that classic theimedynamics was of limited use fer many seil water interactions (Takagi, 1966), and that the amount of unfrezen water belew ${ }^{\circ} \mathrm{C}$ was, ameng ether facters, related to the particle size of the sediment, i.e. the finer the sediment, the greater the amount of unfrezen water (Nerseova and Tsytevich, 1966). Medem studies have shewn that liquid water can be found in soils and ether perous media at temperatures as lew as $-40^{\circ} \mathrm{C}$, i.e. well below the bulk melting temperatures (Cahn et al., 1992; Maruyama et al., 1992, ameng ethers) er even at $-8{ }^{\circ} \mathrm{C}$ in the interstices of shallew hypersline seils in the Antarctic celd deserts, a plausible equivalent te Martian envirenmental cenditions (WynnWilliams et al., 201). The process has been alse studied by Landis (201), whe relates the lowering of the freezing point to capillary-pere effects $\left(-63^{\circ} \mathrm{C}\right)$. Altheugh seils de freeze (e.g. per mafrests in celd regiens), the process is net necessarily complete, and a geod example is previded by the se-called taliks, i.e. localized unfrezen layers lecatod underneath or within masses of permafrest (AIcene, 201; 
Pidwirny, 2002). Taliks occur below rivers and lakes, where strong springs emerge, or can be totally detached from the surface, surrounded by permafrost (closed taliks; Pidwirny, 2002). This hydrological feature may be particularly relevant to the Gorgonum case, because as Costard et al. (2001) have noted, the most spectacular erosion landforms on Mars occur precisely at the intersection between crater rims and wrinkle ridges, which display similar characteristics to taliks observed in Siberia, suggesting that these Martian features may represent perched taliks. Furthermore, Andersen et al. (2002) relate the existence of cold springs $\left(+6^{\bullet} \mathrm{C}\right.$; low-temperature brines) in permafrost from the Canadian High Artic (Axel Heiberg Island; mean annual temperature of $-15^{\circ} \mathrm{C}$ ) to possible equivalent scenarios on Mars.

\section{An alternative view: non-equilibrium systems}

The concept of hysteresis basically refers to a retardation of the effect when forces acting upon a body are changed. In the case of liquids, the hysteresis freezing temperature, as opposed to the thermodynamic freezing temperature, is defined as the limit of metastability of the liquid phase during freezing (Radhakrishnan et al., 2000). Cooling runs on water in porous materials show still pure liquid at $-29^{\circ} \mathrm{C}$. An abrupt change from liquid to solid is observed at $-31^{\circ} \mathrm{C}$, whereas a complete transformation to the solid phase occurs at $-45^{\circ} \mathrm{C}$ (Morishigue and Kawano, 1999). Liquids can be supercooled below the thermodynamic freezing transition because of the presence of a kinetic barrier to crystallization (Morishigue and Kawano, 1999). This phenomenon is particularly important in small, completely confined spaces where kinetic energy is substantially reduced. In other words, the freezing temperature, as compared to the bulk temperature, can be severely depressed in confined spaces, i.e. porous media (Radhakrishnan et al., 2000):

$$
\Delta T_{\mathrm{m}}=T_{\mathrm{m} \text {.pore }}-T_{\mathrm{m} \text {.bulk }}<\bullet
$$

where $T_{\mathrm{m}}$ is the temperature of melting, $T_{\mathrm{m} \text {.pore }}$ is the temperature of melting in the pores and $T_{\mathrm{m} \text {.bulk }}$ is the temperature of melting in the bulk, thus allowing the existence of liquid water up to extremely low temperatures (Cahn et al., 1992; Maruyama et al., 1992; Morishigue and Kawano, 1999; Radhakrishnan et al., 2000 , among others). In turn, the depression of $T_{\mathrm{m}}$ is proportional to $H^{-1}$ (where $H$ is the pore width) as predicted by the Gibbs-Thompson equation (Sliwinska-Bartkowiak et al., 1999).

If dissolved salts are present (e.g. as is probable on Mars; Wynn-Williams et al. 2001; Knauth and Burt, 2002), these effects can be enhanced by two mechanisms: (a) further depression of the freezing point, controlled by the concentration and nature of salts in solution (e.g. about $-56^{\circ} \mathrm{C}$ for the $\mathrm{H}_{2}-\mathrm{NaCl}-\mathrm{KCl}-\mathrm{CaCl}_{2} \quad$ system; Konnerup-Madsen, 1979); and (b) salt rejection, because pure water tends to freeze at a freezing front, leaving a progressively more concentrated solution (and therefore with an even more depressed freezing point) (e.g. Parameswaran and Mackay, 1996). Additionally, as noted by Dickinson and Rosen (2003), a variety of brine solutions can maintain an aqueous phase to $-50^{\circ} \mathrm{C}$, which is well within the range of summer surface temperatures on Mars.

The pressure governing the liquidsolid system in the Martian case under study is the internal pressure $\left(\boldsymbol{P}_{\text {int }}\right)$ within the mudflow, and not the atmospheric pressure acting on the surface of the planet. Given the extremely low values of the atmospheric pressure ( $\boldsymbol{P}_{\text {atmos }}$ ) on the Martian surface, then $\boldsymbol{P}_{\text {int }}>\boldsymbol{P}_{\text {atmos }}$, which will further increase stability of the liquid phase. For example, given a mudflow thickness of $10 \mathrm{~m}$ (a reasonable estimate for a 2-km-long deposit) a point in the middle of the flow would be subjected internal pressures of about $1470 \mathrm{~g} \mathrm{~cm}^{-2}$ (sediment - liquid water $1: 1 ; G_{\text {Mars }}=G_{\text {earth }} \times \mathbf{0 . 3 7 5}$ ), i.e. the equivalent to $\sim 1440 \mathrm{mbar}$.

One may argue that metastable water would freeze under a noticeable strain, such as the movement of a mudflow (metastability breaking); however, although this may be a reasonable argument in the case of free (bulk) water, it can hardly apply to the case under consideration. Given that: (1) viscosity has an exponential dependence on temperature (e.g. Mur- rel and Jenkins, 1994); (2) we are dealing with a very low-temperature fluid (confined to a porous medium), and therefore of higher viscosity; and (3) metastibility of a fluid phase depends (among other factors) on viscosity, i.e. the higher the viscosity the harder to break metastability, it follows that we may expect the integrity of a mudflow to be maintained, at least for a short distance, as shown by the example of Gorgonum crater.

Thus we suggest that the metastable behaviour of water in a porous material (coupled with the effective pressure within the sediment: $\boldsymbol{P}_{\text {int }}$, and high salinity) offers an alternative and plausible explanation for the stability of liquid water, thus opening new perspectives for understanding sediment transport under fluidized conditions on the Martian surface. We further suggest that the physics of non-equilibrium systems may also provide an alternative or complementary approach for understanding taliks on Earth.

\section{Other related phenomena in East Gorgonum Crater}

We suggest that the origin of the deeply entrenched channels bounding the Gorgonum mudflow deposit (Fig. 1 b,c) may be related to syneresis-type phenomena (separation of a liquid from a gel; or in this case, from a fluidized sediment). If, as expected, a mudflow laterally leaks water during movement, then lateral water-excavated channels may form (Fig. 2). In turn, this water may both promote rapid erosion and sediment transport of fine unconsolidated sediments. In the Gorgonum case the erosion channels are not much longer than the associated mudflow (Fig. 1b,c), which indicates that channel-forming processes may have been related to lateral water segregation from the fluidized sediment (see also Fig. 2 for comparison). Furthermore, if the rejected liquid is a brine (e.g. Wynn-Williams et al., 2001), then we would expect a lower freezing point and higher boiling point. Because liquid water would rapidly evaporate (in this case $\boldsymbol{P}_{\text {atmos }}$ controls the system) it is clear that this phenomenon is highly transient. However, given that a phase change from liquid to gas would not be instantaneous for the total amount of rejected 


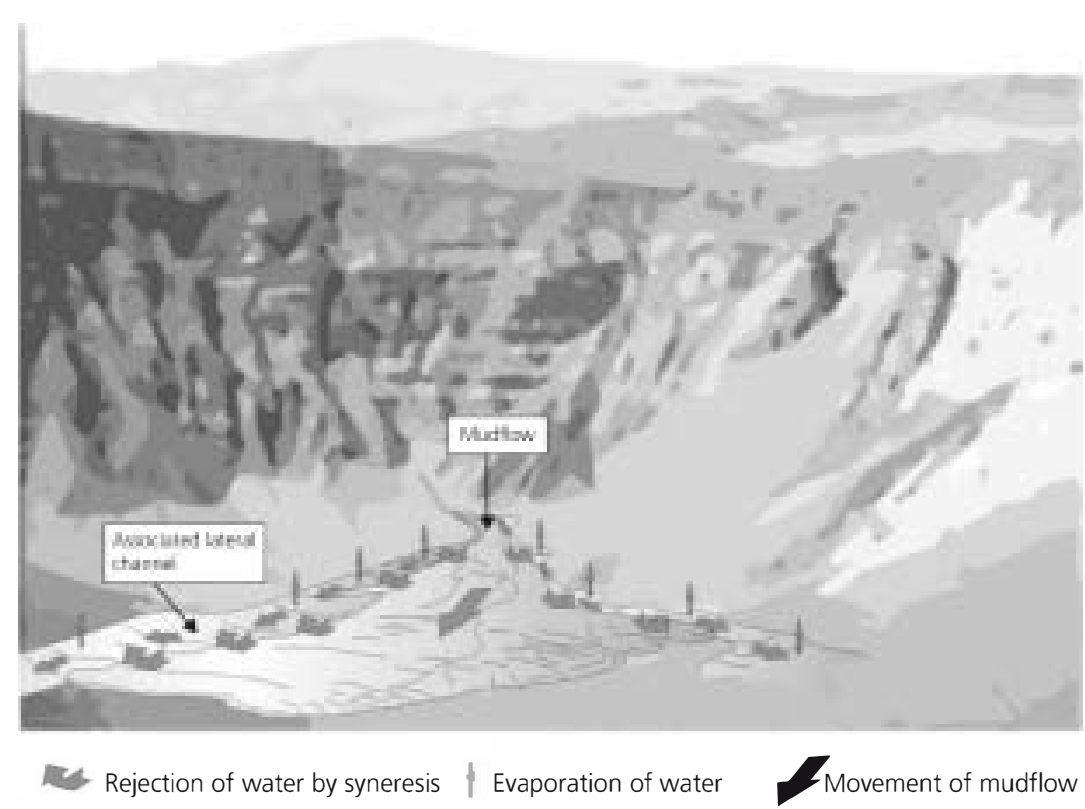

Fig. 3 Simplified model for East Gorgonum type mudflows on Mars. Note the associated lateral channels (compare with Fig. 2) that may be excavated by water rejected by syneresis.

water, part of it would remain as such during the downslope movement of the mudflow. Moreover, as the mudflow advances, more liquid water would be laterally rejected and added to the system as a result of syneresis (Fig. 3). The steeper the slope (as in Gorgonum)
(Fig. 1a), the higher the energy of the running water, and therefore, the deeper the trenches (V-type channels) that can be excavated in the unconsolidated sediments (Fig. 1b,c).

Finally, inspection of the crater image (Fig. 1a) shows that the series of deeply entrenched channels and debris aprons occur only in the northern half of the crater. Malin and Edget (2000) suggest that this is due to climatic and geographical factors. An alternative explanation for this asymmetrical phenomenon might be related to the regional slope, which decreases in altitude to the south. If groundwater exists within a specific regional stratigraphic horizon, this should leak along the northern face of basins and/or craters, following the regional slope (Fig. 4), which is also observed in the northern faces of canyons in the so-called Gorgonum Chaos, some $100 \mathrm{~km}$ to the west of the crater (Malin Space Systems, 2001).

\section{Conclusions}

The physics of non-equilibrium systems offers an alternative view regarding the debate on the existence of liquid water over the Martian surface. We provide theoretical evidence suggesting that liquid water can defy thermodynamics rules, providing that it is confined to porous media (as we would expect within a mudflow). Kinetic restrictions during phase changes of water (and not equilibrium temperatures) need to be taken into account. The process can be enhanced if dissolved salts are present. Internal
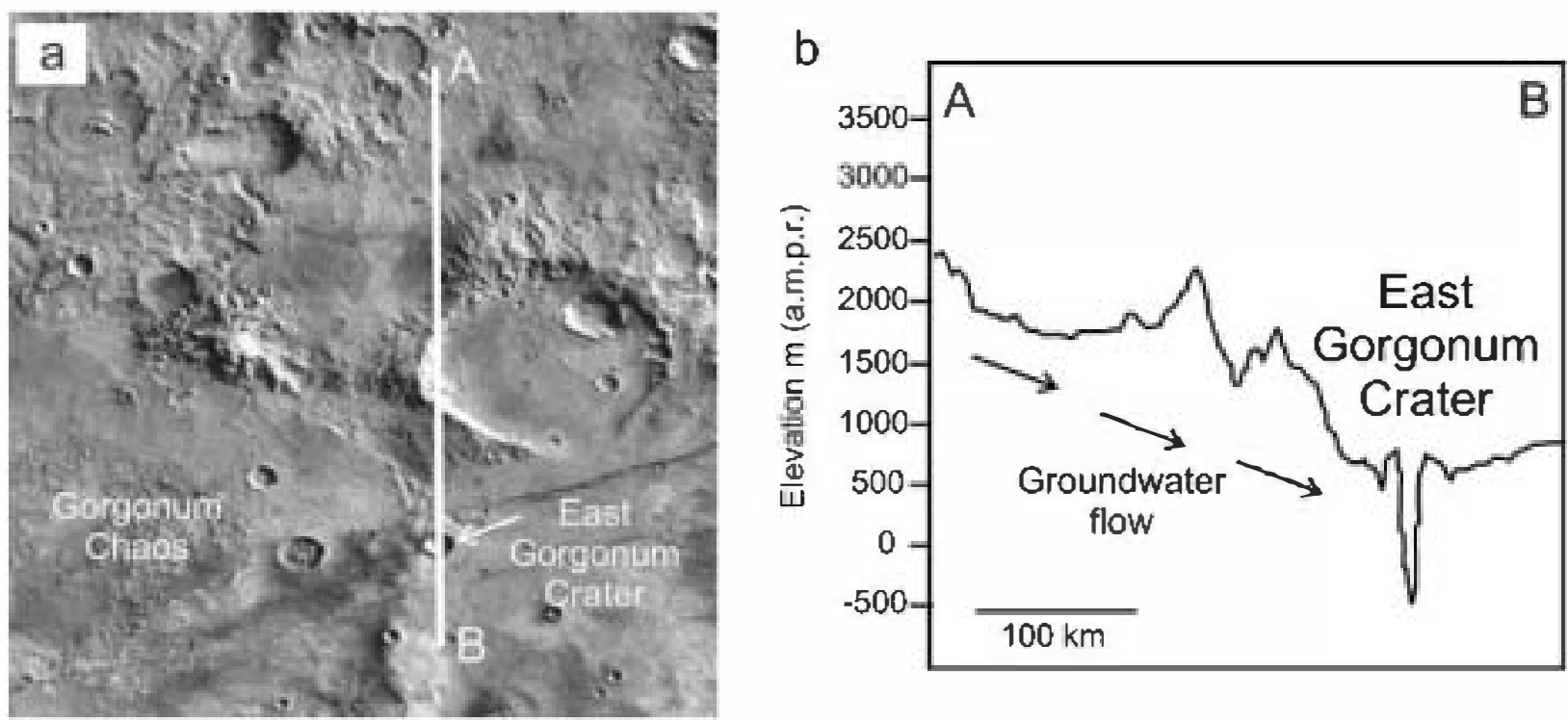

Fig. 4 (a) Viking image mosaic showing the location of East Gorgonum crater and Gorgonum Chaos. (b) Vertically exagerated $\mathrm{N}-\mathrm{S}$ topographic profile (see location in a; High-Resolution MOLA Digital Elevation Model; http://marsoweb.nas.nasa.gov/ dataViz/). Arrows indicate the possible pathway for groundwater moving along the regional slope. A.m.p.r. $=$ above mean planetary radius. 
pressure within the flow, and not that acting on the Martian surface, needs to be considered. The non-equilibrium conditions met within a downslope moving mudflow provide a plausible environment to allow liquid water displacement on the Martian surface (Fig. 3). Furthermore, although we may be describing a highly transient phenomenon, water rejection from the mudflow due to syneresis-type phenomena provides an alternative mechanism to account for the deeply entrenched channels flanking mudflow deposits on the Martian surface (Figs la-c and 3).

\section{Acknowledgments}

This paper benefited fr $\bullet$ c $\bullet$ mments fr $\bullet$ Dr P. B. Black. We thank Dr F. Anguita for his encouragement and help with the manuscript.

\section{References}

Andersen, D.T., P•llard, W.H., McKay, C.P. and Heldman, J., 2002. Cold springs in permafrest on Earth and Mars. J. Geophys. Res., 107, Digital -bject Identifier (D@I): 10.1029/ 2000JE001436.

Arcøe, S.A., 2001. Stratigraphic prøfiling with ground-penetrating radar in per-

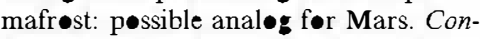
ference on Geophysical Detection of Subsurface Water on Mars (http://Www. lpi.usra.edu/meetings/geomars2001/ geomars2001.resøurce.html.)

Baker, V.R., 2001. Water and the Martian landscape. Nature, 412, 228-236.

Cahn, J.W., Dash, J.G. and Haiying, F., 1992. The ry of ice premelting in

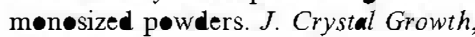
123, 101-108.

Christensen, P.R., 2003. Førmation of recent Martian gullies through melting -f extensive water-rich sn॰w dep•sits. Nature, 422, 425-427.

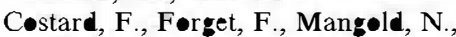
Mercier, D. and Peulvast, J.P., 2001 Debris fløws on Mars: comparisøn with Terrestrial analogs. Conference on the Geophysical Detection of Subsurface Water on Mars (http:// www.lpi.usra.edu/meetings/ geomars2001/pdf/7017.pdf ).

Costard, F., Førget, F., Mangøld, N. and Peulvast, J.P., 2002. F•rnnation of recent Martian debris flows by melting of nearsurface grøund ice at high $\bullet$ bliquety Science, 295, 110-113.

Coussøt, P. and Meunier, M., 1996 Reconition, classification and mechanical description of debris flows. EarthSci. Rev., 40, 209-227.

Dickinsøn, W.W. and Røsen, M.R., 2003. Antarctic pernafrest: an analøgue før water and diagenetic minerals $\bullet$ Mars. Geology, 31, 199-202.

Gilmore, M.S. and Phillips, E.L., 2002 R॰le of aquicludes in formation of Martian gullies. Geology, 30, 1107-1110.

Hartmann, W.K., 2001. Martian seeps and their relation to youthful geothermal activity. In: Chronology and Evolution of Mars (R. Kallenbach, J. Geiss and W. K. Hartmann, eds), pp. 405-410. Kluwer, New York

H॰ffman, N., 2000. White Mars: a new mødel for Mars'surface and atmøsphere based on $\mathrm{CO}_{2}$. Icarus, 146, 326-342.

Jakısky, B.M. and Phillips, R.J., 2001 Mars' volatile and climate hist•ry. Nature, 412, 237-244.

Knauth, L.P. and Burt, D.M., 2002. Eutectic brines on Mars: rigin and pøssible relation t॰ y॰un seepage features. Icarus, 158, 267-271.

K॰nnerup-Madsen, J., 1979. Fluid inclusions in quartz from deep-seated granitic intrusions, søuth Nørway. Lithos, 12, 13-23.

Landis, G.A., 2001. Martian water: are there extant haløbacteria on Mars? Astrobiology, 1, 161-164.

Malin Space Systems, 2001. Evidence for recent liquid water on Mars: channels and aprøns in East Gør gonum Crater, http://mars.jpl.nasa.gov/m /msss/ camera/images/june2000/e._crater/ index.html.

Malin, M.C. and Edget, K.S., 2000. Evidence for recent groundwater seepage and surface run॰ff $\bullet$ Mars. Science, 288, 2330-2335.

Maruyama, M., Bienfait, M., Dash, J.G and Coddens, G., 1992. Interfacial melting of ice in graphite and talc powders. J. Crystal Growth, 118, 33-40.

Melløn, M.T. and Phillips, R.J., 2001. Recent gullies $\bullet$ Mars and the source of liquid Water. J. Geophys. Res., 106, 23,165-23,179.

Mørishigue, K. and Kawan•, K., 1999. Freezing and melting of water in a single cylindrical pore: the pore-size dependence of freezing and melting behavior $J$. Chem. Physics, 110, 4867-4872.

Murrel, J.N. and Jenkins, A.D., 1994 Properties of Liquids and Solutions. J•hn Wiley \& Sons, New York.

Nasa Ames Mars General Circulation Mødel, 2002. Climate Catalog. http:// humbabe arc.nasa $.0 v / \mathrm{mcc} / \mathrm{CC} . \mathrm{html}$; accessed, September 2002.

Nerseøva, Z.A. and Tsytøvich, V.A., 1966. Unfrøen water in frøzen søils. In: Proceedings, Perma frost International Conference, La ayette, November 1963 (K.B.

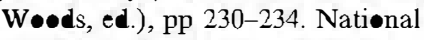
Academy $\bullet$ Sciences - Natiønal Research Council.

Parameswaran, V.R. and Mackay, J.R., 1996. Electrical freezin potentials measured in a ping• grøwing in the western Canadian Artic. Cold Regions Sci. Technol., 24, 191-203.

Pidwirny, M.J., 2002. Fundamentals of physical geography. Http://www.

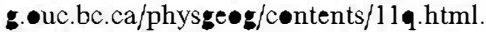

Radhakrishnan, R., Gubbins, K.E. and Sliwinska-Bartk•wiak, M., 2000. Effect of the fluid-wall interaction on freezin: -f confined fluids: toward the development of a lıbal phase diagram. J. Chem. Physics, 112, 11048-11057.

Sliwinska-Bartk•wiak, M., Gras, J., Sikørski, R., Radhakrishnan, R., Gelb, L. and Gubbins, K.E., 1999. Phase transition in peres: experimental and simulation studies of melting and freezing. Langmuir, 15, 6060-6069.

Takagi, S., 1966. The ry of freezing-pøint depression with special reference to søil water. In: Proceedings, Perma frost International Conference, Lafayette,

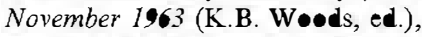
pp. 216-224. National Academy of Sciences - National Research Council. Wynn-Williams, D.D., Cabrøl, N.A., Grin, E.A., Haberle, R.M. and Støker, C.R., 2001. Brines in seepage channels as eluants for surface relicts biømølecules $\bullet$ Mars? Astrobiology, 1, 165-184. 